\title{
A DIGNIDADE DA PESSOA HUMANA E O DIREITO À VIDA DO NASCITURO: FUNDAMENTOS BIOLÓGICOS, FILOSÓFICOS E JURÍDICOS
}

THE DIGNITY OF THE HUMAN PERSON AND THE UNBORN' S RIGHT TO LIFE:BIOLOGICAL, PHILOSOPHICAL AND LEGAL FOUNDATIONS

\author{
Mário da Silva Ribeiro \\ Victor Sales Pinheiro
}

\section{RESUMO}

Explicando o sentido da dignidade da pessoa humana e o alcance do direito à vida do nascituro, este artigo demonstra por que o aborto voluntário carece de fundamentação racional. Para tanto, no âmbito da interdisciplinaridade, relaciona Biologia, Filosofia e Direito em três partes: 1) considerações biológicas sobre quando e como uma realidade individual humana surge; 2) as dimensões antropológica e ética do ser humano à luz das lições de Tomás de Aquino; e 3) a tutela jurídica dada ao nascituro no Código Penal brasileiro e na Arguição de Descumprimento de Preceito Fundamental no 54. Com isso, contribui para a elucidação de um tema complexo da Bioética contemporânea.

Palavras-chave: Aborto voluntário. Nascituro. Direito à vida.

\section{ABSTRACT}

Explaining the meaning of the dignity of the human person and the extent of the right to life of the unborn, it shows why voluntary abortion lacks rational foundation. To do so, within the scope of interdisciplinarity, it relates Biology, Philosophy and Law in three parts: (1) the biological considerations about when and how a human individual reality arises; (2) the anthropological and ethical dimensions of the human being in the light of Thomas Aquinas's lessons; and (3) the legal protection given to the unborn in the Brazilian Penal 
Code and in the Claim of Breach of Fundamental Precept no 54. With this, it contributes to the elucidation of a complex theme of contemporary bioethics.

Keywords: Voluntary abortion. Unborn. Right to life.

\section{INTRODUÇÃo}

A temática do aborto voluntário e, naturalmente, da extensão do direito à vida, pode ser desdobrada em diversos prismas. Pode-se apreciá-la em termos histórico-culturais, sociológicos, psíquicos, teológicos, entre outros tantos infindáveis tipos de saber. 0 enfoque, no entanto, que substancia o presente artigo se fundamenta antes na tríade Biologia, Filosofia e Direito, três distintos tipos de conhecimento que, juntos, fornecem mais segurança conceitual a essa complexa questão contemporânea.

Se no passado as discordâncias quanto à prática abortiva voluntária estavam predominantemente atreladas ao momento em que se inicia a vitalidade do nascituro, nos dias de hoje elas vão adiante, abordando com maior profundidade categorias como natureza, personalidade e dignidade. Preocupa-se se há vida no ventre materno e se esta vida é humana; se a vida, sendo humana, é concomitantemente típica de uma realidade pessoal; e, ainda, se existindo vida humana e personalizada, há como se reconhecer um ser digno em si mesmo e sujeito de direitos fundamentais. Nos tempos atuais, portanto, os olhares estão voltados para além de uma possível existencialidade do embrião ou do feto, questionando-se se estes são pessoas humanas cuja vida se impõe como um direito basilar inerente à sua dignidade intrínseca.

Não é por outra razão que a problemática do aborto se intensificou de maneira significativa no cenário jurídico brasileiro quando o Supremo Tribunal Federal (STF), valendo-se de dados biológicos e considerações filosóficas, decidiu descriminalizar o aborto de fetos anencefálicos, ao julgar a Arguição de Descumprimento de Preceito Fundamental no 54, em 2012 (BRASIL, 2012). Esforço interdisciplinar semelhante, embora a priori substancialmente distinto, verifica-se atualmente no Congresso Nacional, onde diferentes parlamentares, na tentativa de ordenar o fenômeno jurídico pátrio a uma suposta melhor compreensão biológica e ética do ser humano, 
estabeleceram como um dos pontos centrais da pauta legislativa a análise da Proposta de Emenda à Constituição (PEC) 181/2015. Tal propositura visa, entre outras coisas, determinar que o direito à vida deve ser juridicamente tutelado desde a concepção, o que efetivaria, a nível constitucional, maior proteção ao nascituro (BRASIL, 2015).

Estas são, é claro, apenas algumas ilustrações nacionais da interdisciplinaridade que envolve o tema aqui em apreço; tema este que tem sido marcado pelas mais distintas indagações e repostas. Na realidade, não obstante as diretrizes já existentes no plano da dogmática jurídica consolidada em diferentes países, a temática do aborto continua a gerar dissidências extremas. Vários fatores poderiam ser invocados nesse sentido: a preocupação pelos problemas que envolvem a vitalidade; a compreensão do indivíduo humano e de seus direitos e deveres fundamentais; ou mesmo a afirmação de que a mulher deve ser livre para eliminar aquilo que impõe diretrizes ao seu corpo.

Juntas a essas razões outras poderiam ser lembradas, mas pouco esforço é exigido para se perceber, ao menos de maneira preliminar, que qualquer análise rigorosa quanto à interrupção voluntária da gravidez não deve estar adstrita a discussões meramente verbais e contraposições genéricas fundadas em polêmicas infecundas. Antes, a análise de uma questão primordial como esta deve basear-se num raciocínio sóbrio e preciso, ordenando os fatos segundo laços objetivos de causalidade e, ao mesmo tempo, considerando as conexões de sentido que compõem o problema.

Daí que, em busca de uma síntese que melhor contribua para a compreensão a respeito do aborto, exprimir as mais coesas e convincentes explicações de aspectos empíricos da realidade em conjunto com a análise filosófica e as investigações das ciências sociais é algo cada vez mais necessário. Assim o fazem, por exemplo, Peter Singer (2002), Joel Feinberg (1984), John Finnis (1993) e George e Tollestsen (2008), que, entre outros tantos estudiosos contemporâneos, utilizam da Biologia, da Filosofia e do Direito como conhecimentos complementares que oferecem o rigor de raciocínio para a solução das situações de conflitos relacionadas ao aborto.

Em verdade, sem o diálogo entre esses três diferentes campos 
científicos - Biologia, Filosofia e Direito - não seria possível fundamentar, com critérios racionalmente válidos, normas jurídicas aptas a responder às dúvidas relativas à racionalidade do aborto voluntário. Isso significa que, desse encontro interdisciplinar, amadurecem a compreensão científica do direito à vida e do direito à liberdade sobre o próprio corpo. Essa análise bioética e biojurídica possibilita que a consubstanciação de direitos relacionados à atividade abortiva se efetive a partir de informações mais completas e precisas sobre os seus fatos constitutivos. Isto é, constatações cuja evidência, em determinado período histórico, indica a verdade científica, a validade moral e a tutela jurídica da sociedade política.

A questão do aborto exige mais do que uma mera exposição sistemática das normas vigentes em determinado ordenamento jurídico, assim como transcende ao singelo estudo dos problemas relativos à interpretação e à aplicação do direito. Uma abordagem reducionista como esta, que não atenta ao imperativo interdisciplinar, negligencia a complexidade do problema enfrentado, pois dispensa os conhecimentos biológicos e filosóficos necessários para uma compreensão elementar da questão. Como bem lembra Tércio Sampaio Ferraz Júnior (2010), a Ciência Jurídica não diz o que é direito em tal e tal circunstância, e sim o que deve ser direito conforme as reflexões sobre as circunstâncias existentes.

De fato, o problema bioético do aborto exige o tratamento articulado entre a ciência humana do direito e a ciência natural da biologia a partir das dimensões antropológica e ética de uma filosofia que as relaciona. Biologia, Filosofia e Direito precisam, pois, estar integrados para que o ordenamento jurídico normatize, efetivamente, as relações sociais, não se escusando da precisão e objetividade que o tema regulado exige.

Para um assunto como a interrupção da gravidez, apreciado sob tantas particularidades, de maneira que "os diferentes impulsos e convicções expressos nas interpretações concorrentes são muito vigorosos e apaixonados" (DWORKIN, 1993, p. 70, tradução nossa), é inevitável a complementaridade de saberes diversos para o aperfeiçoamento da argumentação intelectual do debate público e para o reconhecimento da contribuição das assertivas dos interlocutores nele envolvidos.

Assim, justificada a importância do tema e a necessidade de uma 
análise interdisciplinar, este artigo tem como objetivo analisar, à luz da relação entre Biologia, Filosofia e Direito, se o aborto voluntário goza de algum fundamento racional e, por conseguinte, verificar se, ou até que ponto, o direito à vida diz respeito à figura do nascituro. Considerando o desafio intelectual que tal objetivo apresenta, serão analisadas, com a profundidade necessária, (1) as considerações biológicas sobre quando e como uma realidade individual humana surge; (2) as dimensões antropológica e ética do ser humano à luz das lições de Tomás de Aquino; e (3) a tutela jurídica dada ao nascituro no Código Penal brasileiro e na Arguição de Descumprimento de Preceito Fundamental no 54 . Este artigo enfrenta, portanto, (1) a questão biológica do começo da vida humana; (2) a questão filosófica (antropológica e ética) da dignidade da pessoa humana; e (3) a questão jurídica do direito à vida, contribuindo para o controvertido debate atual sobre o aborto voluntário, com respostas objetivas às seguintes perguntas: Quando começa a vida? O nascituro é um ser humano? Ele goza de personalidade ou dignidade? Caso ele seja pessoa humana digna, em que medida é legítimo abortá-lo?

Em relação à metodologia, por fim, o presente artigo faz uso de uma abordagem teórico-reflexiva pautada na articulação de conceitos biológicos, filosóficos e jurídicos e baseada em bibliografia científica autorizada e atualizada, a fim de confrontar a tutela jurídica nacional do nascituro no Código Penal brasileiro e na Ação de Descumprimento de Preceito Fundamental no 54. Em outras palavras, este artigo utiliza o método comum às ciências humanas, o método explicativo-compreensivo (FERRAZ JÚNIOR, 2010), na tentativa de explicar e compreender os aspectos lógicos e as questões axiológicas do tema e objetivo indicados.

\section{CONSIDERAÇõES BIOLÓGICAS SOBRE O NASCITURO}

Esta seção se dedica à compreensão dos dados biológicos oferecidos pela embriologia e genética contemporâneas sobre o desenvolvimento do nascituro. Nela, apresenta-se um panorama dos quinze primeiros dias de amadurecimento do embrião; infere-se o que este processo de maturação comunica logicamente; e analisam-se criticamente as duas 
principais objeções à individualidade embrionária.

\section{O EMBRIÃO É UM TODO VIVO E HUMANO}

A segunda metade do século XX esteve marcada por um significativo progresso no âmbito das ciências biológicas. A partir de 1953, quando James Watson e Francis Crick anunciaram o modelo de estrutura do ácido desoxirribonucleico (DNA, da sigla em inglês, ou ADN, da sigla em português), novidades e conquistas, no mundo da Biologia, não mais cessaram. Dos avanços, beneficiaram-se não só homens de hoje, mas se beneficiarão os homens de amanhã.

Concomitantemente, no entanto, nem sempre os progressos das ciências biológicas estiveram ligados ao substrato ético que deve guiar todo e qualquer cientista. Pressionados pelo pluralismo ideológico e pelo deserto axiológico fomentado já no século XIX, que resultou nas duas grandes guerras mundiais do século $\mathrm{XX}$, muitos estudiosos fizeram de seus conhecimentos um instrumento para uma ciência inconsequente, desprovida de balizas morais consistentes. A consideração do embrião humano como singelo produto de uma relação sexual, um aglomerado de células, talvez seja o mais conhecido dos exemplos que poderiam ser oferecidos. Em verdade, na década de 1980, expandiu-se pelo universo biomédico, jurídico e acadêmico, que o recém-concebido - até o décimo quarto dia após a fecundação, momento em que se completa o processo de implantação no útero materno - não passava de uma massa anônima crescente em um corpo hospedeiro. Consequentemente, a esse objeto disponível se negava a condição e valor de ser humano.

Tal perspectiva, ainda hoje, quando mais do que nunca o dinamismo tecnológico acompanha o saber, continua a ser levantada para justificar o aborto. Diz-se que antes da nidificação inexiste vida humana intrauterina, porque não há um ser individualizado, no máximo um acúmulo celular. A esse prisma se alinha a Organização Mundial da Saúde (OMS), segundo a qual a gravidez inicia somente com o implante pleno do neoconcebido (WORLD HEALTH ORGANIZATION, 1987).

Quer parecer, porém, que a simples descrição objetiva dos quinze 
primeiros dias de desenvolvimento embrionário humano conduz a uma conclusão diferente. Nesse breve período já subsistem todos os dados necessários para se afirmar que, com a concepção, se concretiza um ser humano inédito. De fato, durante esse processo há a fusão do material genético de duas células haploides - um espermatozoide e um ovócito -, as quais, uma vez integradas, dão origem a uma única e distinta célula, agora diploide, o embrião unicelular dotado de quarenta e seis cromossomos (vinte e três maternos e vinte e três paternos).

Uma vez concluída a fecundação, o novo embrião, conhecido também como zigoto, inicia em vinte quatro horas a sua divisão inaugural, atingindo o ápice segmentatório cerca de seis horas mais tarde. No segundo dia, ocorre outra clivagem, momento em que se consolidam quatro células. Ao final do terceiro dia, dezesseis células já existem, e, após o quarto dia, o número de células aumenta à medida que a esfera celular, agora intitulada mórula, se movimenta ao longo da tuba uterina em direção ao útero. Por volta do quinto dia, estando livre no útero materno, uma secreção proveniente das glândulas uterinas e rica em glicogênio penetra na mórula, acumulando-se entre as suas células, de modo a permitir a formação de uma cavidade interna repleta de líquido, conhecida como blastocele, bem como o surgimento de duas linhas celulares: o trofoblasto (camada superficial externa de células) e o embrioblasto (massa celular interna). Com tal rearranjo, o embrião multicelular passa a ser chamado de blastocisto (LARSEN, 2001).

Durante esse período de aproximadamente cinco dias, a rápida multiplicação de células obedece aos comandos do novo genoma. É ele quem controla os principais eventos do processo de clivagem e a produção de proteínas, sem as quais a estruturação e funcionalidade das novas células não se faria possível. É ao novo genoma, igualmente, que se vincula a interação intercelular nesse período. Isso porque, quando o número de células aumenta, estas majoram as suas áreas de contato, trocando sinais e moléculas fundamentais para o desenvolvimento normal do embrião. Sem a permissão dos genes embrionários isso seria impossível (LARSEN, 2001; SERRA, 2004).

É fundamental notar também que, apesar de ter centenas de células, o blastocisto ainda tem praticamente o mesmo tamanho de quando ainda era unicelular. Cerca de seis dias da fecundação, contudo, ele se expande 
e inicia o processo de implantação ou nidação, com o embrioblasto voltado em direção à mucosa que reveste a parede uterina, o endométrio. Entre o sétimo e o oitavo dia, as células do trofoblasto se diferenciam graças a ativação de diferentes genes embrionários, originando camadas celulares que irão ser importantes para a constituição do córion (uma das membranas fetais). No mesmo período, também no embrioblasto - e igualmente seguindo as diretrizes do genoma - se manifesta uma diferenciação: distinguem-se o hipoblasto (endoderma primitivo) e o epiblasto (ectoderma primitivo), células que, em conjunto, formam o disco embrionário, estrutura que, entre o décimo primeiro e o décimo terceiro dia, cresce em diâmetro, e, por volta do décimo quarto ou décimo quinto dia, origina os três folhetos germinativos (ectoderma, mesoderma e endoderma) que formarão os tecidos e órgãos do nascituro. É o início da morfogênese (GEORGE; TOLLEFSEN, 2008; LARSEN, 2001; SERRA, 2004).

Pode não parecer à primeira vista, mas esta breve síntese do desenvolvimento embriológico, com enfoque nos quinze dias iniciais do embrião, permite apreendê-lo em sua concretude e dinamismo, isto é, termina por afirmar que:

a) Imediatamente depois da fertilização já existe uma realidade intrinsecamente una e distinta de qualquer outra, um todo singular e não a parte de uma singularidade. 0 embrião, em virtude do seu genoma e perfil epigenético, é capaz de passar por um processo de desenvolvimento contínuo e gradual até a maturidade da sua espécie, e, portanto, um processo que exige uma rigorosa unidade (EBERL, 2006; GEORGE; TOLLEFSEN, 2008; SERRA; COLOMBO, 2007; PAYNE, 2014). Isso fica muito claro quando se verifica que, sob o comando do novo genoma, há uma coordenada sequência de atividades (ativação e regulação do ciclo mitótico, produção de proteínas, interação química entre células, diferenciação celular, etc.).

b) Mais do que um todo, o embrião é um todo vivo. Ao estar cingido pela atividade de diferentes genes que o orientam ordenadamente a um amadurecimento, o embrião manifesta a mais básica propriedade de qualquer ser vivente: coordena- 
ção. Ou seja, a disposição para que as mudanças estruturais e funcionais pelas quais passa se deem de acordo com um centro informativo e coordenador, no caso, o genoma. Tal vitalidade fica mais clara ainda quando se verifica que, uma vez orientado por suas informações genéticas, o embrião é naturalmente uma realidade que comunica e recebe estímulos, quer dizer, uma realidade excitável, bem como um todo que herda caracteres, caracteres esses que garantem a sua potencialidade reprodutiva e viabilidade evolucionária. Em outras palavras, o embrião é um todo dotado de coordenação, excitabilidade, herança de características, reprodutibilidade e tendência evolutiva - qualidades próprias de qualquer entidade viva (SERRA; COLOMBO, 2007).

c) Por fim, este todo vivo é também um todo humano, porquanto, além de comportar todas as moléculas de DNA típicas do gênero Homo sapiens, está envolvido pela atividade de genes que possibilitam o seu desenvolvimento até a plenitude de tal gênero. Assim, embora uma célula somática possua o mesmo genoma que o zigoto ou o embrião pluricelular, a sua faceta epigenética é completamente distinta (ANDERSON, 2007; EBERL, 2006; PAYNE, 2014). De fato, o estado epigenético das células somáticas sequer se relaciona com o desenvolvimento de um todo conforme a sua natureza; abrange tão-somente a estrutura e funcionalidade de uma parte que compõe um todo.

Vê-se, pois, que o embrião é um todo vivo e humano desde a concepção. 0 seu amadurecimento exige uma realidade ontologicamente singular e viva, que se estrutura como um ser preenchido pela humanidade. Ou melhor: importa um indivíduo real, estranho a qualquer anonimato, porquanto já individualizado na espécie humana.

Neste ponto, não seria injusto, no entanto, emergir uma dúvida. Como pode o embrião humano ser um indivíduo, se a individualidade pressupõe a ausência de divisão? A resposta é simples e verificável no próprio desenvolvimento embriológico supra: o concepto, embora sujeito a diversas clivagens, é um indivíduo porque nunca perde a organização 
íntima que se constitui, desde a concepção, com o propósito de preservar a sua vida - ainda que as partes que contribuem para essa organização, verdadeira unidade, perpassem por alguma mudança, ou mesmo deixem de existir (SERRA, 2004). Pense-se, por exemplo, no embrião unicelular. Há nele distintos elementos, cada um com uma função própria, mas nenhuma dessas funções se desenvolve como atividade per se; cada elemento só existe e tem um porquê em razão da vitalidade consubstanciada. Ao longo da embriogênese, elementos vários permanecem intactos (como o genoma, em geral), se aprimoram (como o disco embrionário) ou desaparecem (como a zona pelúcida), num processo dinâmico em que não se corrompe nenhuma operação indispensável para se atingir o objetivo comum, que é conservar o todo vivente; isto é, não se corrompe a organização íntima necessária à vida. Assim, com o zigoto, aflora uma realidade viva, irredutível às partes componentes; aflora uma harmonia organicamente inquebrantável.

Isto posto, apreciadas objetivamente as primeiras fases do desenvolvimento embriológico, mesmo que brevemente, parece não fazer sentido, do ponto de vista ontológico, reduzir o embrião humano ao status de um acúmulo de células. Esta nova realidade, já em sua condição unicelular, é o retrato pleno de um ser humano vivo integralmente individualizado e, de modo consequente - como será visto mais adiante -, provido de uma dignidade de alcance universal.

\section{GÊMEOS MONOZIGÓTICOS E AUSÊNCIA COU INCOMPLETA FORMAÇÃO) DO SISTEMA NERVOSO CENTRAL COMO OBJEÇÕES À INDIVIDUALIDADE DO EMBRIÃO HUMANO}

Além da tese de que o embrião humano, nos seus quinze dias iniciais, é uma simples massa celular, outras duas perspectivas de análise costumam figurar como as principais objeções à vitalidade do neoconcebido, questionando a sua individualidade real.

A primeira dessas objeções é a existência de gêmeos monozigóticos, popularmente conhecidos como gêmeos idênticos. De acordo com os seus defensores, a possibilidade de se desenvolverem, a partir de um único óvulo 
fertilizado, dois indivíduos é a prova de que o zigoto não goza de nenhuma individualidade. Esse é, sem dúvida, o questionamento mais forte à posição anteriormente apresentada, especialmente pelo grande impacto que causa naqueles que o contemplam. Trata-se, com efeito, inobstante a ausência de fundamentos sólidos para sustentá-la, de uma objeção que merece apreço. Daí Angelo Serra e Roberto Colombo - o primeiro, geneticista e filósofo italiano, e o último, professor de biologia e bioética na Universidade de Milão - apresentarem três significativas respostas à proposição levantada.

Preambularmente, ressaltam que a manifestação de gêmeos univitelinos é uma verdadeira exceção: cerca de 99\% dos zigotos não expressam, à medida que se desenvolvem, mais de um organismo. "Isso significa logicamente que o zigoto é determinado per se para desenvolver-se como um indivíduo humano único" (SERRA; COLOMBO, 2007, p. 198).

Em seguida, apontam que estudos recentes corroboram a hipótese de que a formação de gêmeos monozigóticos se dá porque em alguma parte do embrioblasto, em virtude de um eventual erro entre o quarto e o sétimo dia após a concepção, "um plano de desenvolvimento novo e independente é determinado para que um novo ser individual inicie o seu próprio ciclo" (SERRA; COLOMBO, 2007, p. 199). Assim, parece muito razoável, dizem eles, "afirmar que há um primeiro ser humano do qual se origina um segundo ser humano" (SERRA; COLOMBO, 2007, p. 199). Prova disso, entre outras coisas - e esta é a terceira e última consideração -, é a possibilidade de diferença de cariótipo entre os gêmeos idênticos; diferença essa confirmada em muitas pesquisas realizadas nos últimos trinta anos. "Os casos mais notáveis são aqueles nos quais um dos gêmeos monozigóticos tem um cariótipo com 47 cromossomos e é afetado pela Síndrome de Down, enquanto o cogêmeo tem um cariótipo normal com 46 cromossomos" (SERRA; COLOMBO, 2007, p. 199). Essa simples circunstância parece expressiva para colocar em evidência que "o primeiro indivíduo continua o seu próprio curso de desenvolvimento, enquanto o segundo começa o seu próprio ciclo vital assim que o novo plano se torna independente do primeiro" (SERRA; COLOMBO, 2007, p. 199).

Dito em outro tom, a cada um dos gêmeos univitelinos se faz indispensável reconhecer uma individualidade: a do primeiro, desde a fertilização, e a do segundo (ou dos demais), a partir da partição daquele, a 
chamada cisão gemelar. Tal fenômeno garante não só a continuidade do desenvolvimento do embrião vivente com a concepção, mas o início da vida do novo embrião.

A segunda e comum objeção à vitalidade do neoconcebido consiste na inexistência ou formação incompleta do sistema nervoso central. Acreditam os seus adeptos que, não havendo ou enquanto não se formar completamente o encéfalo e a medula espinhal - o que ocorre aproximadamente na oitava semana de gestação -, não é possível reconhecer qualquer individualidade vital ao nascituro, na medida em que apenas tais estruturas são responsáveis por garantir a organização integrada (unidade orgânica) de uma realidade.

Essa posição parece equivocada pela seguinte razão: a unidade orgânica de um indivíduo e, nesse sentido, do embrião, demanda a complementaridade das distintas partes que o compõem, cada uma atuando para atingir um propósito único, a manutenção da vida; nela, os elementos componentes participam de uma dialética de implicação-polaridade, e é essa tensão que assegura uma organização. Por isso diz Alan Shewmon (apud SPAEMANN, 2012a, p. 59, tradução nossa), neurologista norte-americano mais conhecido por suas pesquisas a respeito da morte cerebral, que:

No que diz respeito à vitalidade quanto ao organismo, o papel do cérebro é mais modulador que constitutivo, melhorando a qualidade e sobrevivência potencial de um pressuposto organismo vivo. A unidade integradora de um organismo complexo é uma característica inerentemente não localizável, holística que envolve a interação mútua entre todas as partes, e não uma coordenação vertical imposta por uma parte sobre uma multiplicidade passiva das outras partes.

Não está sendo dito aqui, naturalmente, que o sistema nervoso central (em especial, a sua parte superior, onde se encontra o encéfalo e, por conseguinte, o cérebro) não é, uma vez constituído ou em processo de constituição, essencial para a individualidade de um organismo humano; se está apenas reafirmando aquilo que muitos médicos, biólogos, juristas e filósofos têm confirmado: não é ele a causa da unidade que substancia a individualidade humana, e sim um importante componente dela; um componente que, se eliminado, não gera a sua imediata cessação. 
Não é por outra razão que Mark Siegler e Daniel Wikler (1982) - este, professor de ética e saúde da população na Universidade de Harvard; e o primeiro, um dos principais especialistas em ética médica dos Estados Unidos e diretor fundador do Centro MacLean de Ética Clínica Médica da Universidade de Chicago - afirmam:

Torna-se irresistível falar de pacientes com morte cerebral como sendo "somaticamente vivos" [...] como sendo "doente terminais", e, eventualmente, de "morrer". Estas são maneiras diferentes de dizer que tais pacientes (ou, pelo menos, seus corpos) estão vivos. A morte do cérebro não parece servir como uma fronteira; é uma perda trágica, em última análise fatal, mas não morte por si só. A morte corporal ocorre mais tarde, quando o funcionamento integrado cessar (apud POTTS; BYRNE; NILGES, 2000, p. 131, tradução nossa).

Em verdade, o embrião humano conserva a sua vitalidade e natural individualidade porque goza de uma organização integrada que não tem o sistema nervoso central como razão de ser, mas a exigência operacional mútua dos seus componentes; exigência essa que, como já visto, tem início imediatamente após o fim do processo de fertilização, quando surge o embrião unicelular e o novo genoma.

Assim sendo, vale consignar que as impugnações feitas às objeções apontadas não visam, de maneira alguma, a eliminar a pesquisa científica ou impedir a produção de instrumentos de desenvolvimento; pelo contrário, as investigações da ciência são fundamentais para o progresso e bem-estar da humanidade, permitindo ao homem penetrar em distintos mistérios do mundo. A sede de conhecimento, no entanto, não é justificativa para que se passe por cima da vida de um indivíduo humano. Sem essa responsabilidade ética não há ciência segura.

É por essa razão que, caso ainda subsistam dúvidas após tudo o que foi dito à luz da Biologia, o caminho a ser seguido é o da razoabilidade e prudência: in dubio pro vita. 


\section{O ESTATUTO ONTOLÓGICO DO NASCITURO}

A síntese entre informações científicas e raciocínios filosóficos revela-se uma prática cada vez mais comum nos últimos anos. É somente mediante essa complementaridade epistemológica que se faz genuinamente possível o oferecimento de respostas para os múltiplos problemas éticos e jurídicos oriundos da interferência do homem em diversos aspectos da realidade, em especial da realidade biológica humana.

Seria pouco valioso, nesse sentido, limitar a investigação deste artigo às informações biológicas da seção anterior. 0 conteúdo destas informações tem maior alcance quando compreendido em conjunto com a reflexão filosófica, e a reflexão filosófica ganha sensatez quando se baseia neste conteúdo biológico. Assim, a presente seção trata de três categorias básicas no âmbito da Filosofia, particularmente nas disciplinas da Antropologia e da Ética: natureza, personalidade e dignidade humanas, relacionando-as, no que for possível, com os dados biológicos já apreciados.

\section{CONCEITO, ORIGEM E EFETIVAÇÃO DA NATUREZA HUMANA}

Entre todos os seres, apenas o ser humano é capaz de valorar, de atribuir sentido aos atos e às coisas que o cercam, inclusive a ele próprio. Isso não só o revela como uma entidade irredutível a meros termos biopsíquicos, cuja existência está cingida pela experiência ética, como expressa também a sua capacidade distinta de apreender - com segurança e livre de impressões acidentais - o que se coloca diante de si como verdade, isto é, conhecer.

O conhecimento é produto de um processo que comporta percepção sensorial e abstração, ou, mais precisamente, é resultado daquilo que poderia se denominar singularidade racional. Nenhum indivíduo humano chega a ele sem um trabalho intelectual que exija a assimilação de informações por certo órgão sensorial e a devida intelecção decorrente de algum juízo abstrativo. Conhecendo, o homem torna-se 
capaz de indicar o seu lugar no mundo, tanto do ponto de vista moral individual, quanto da perspectiva social e histórica, percebendo avanços e recuos da humanidade, indagando o que desconhece, e desenvolvendo, em maior ou menor grau, as faculdades que compartilha com os outros seres humanos. 0 ato de conhecer é, por assim dizer, uma chance de crescente penetração nos problemas que se consubstanciam na realidade, e se traduz no ser humano mediante a qualidade ou determinação concreta da racionalidade.

Na tentativa, então, de entender o homem é possível, de imediato, chegar à seguinte conclusão: valores são apreendidos porque se conhece, e se conhece porque a razão apreende a realidade. Constituiria um erro, no entanto, imaginar ser a racionalidade - enquanto propulsora do conhecimento e assimiladora do universo axiológico - o único traço fundante do ser humano, não podendo se esquecer tanto da animalidade quanto da sociabilidade que o conduzem no seu existir; ou melhor: dos impulsos naturais que o acompanham desde a concepção, aqueles vinculados aos aspectos vitais e sensíveis, e da sua propensão, igualmente natural, para compartilhar relações de diferentes gêneros com os seus semelhantes. Na realidade, o homem, ser cognoscente, não traz consigo apenas a força do formalmente lógico e esquemático; ao contrário, no ímpeto de se autopreservar carrega também aquilo que, em geral, é inconsciente e automático, uma espécie de arrebatamento que estimula o organismo vivo a caminhar. Animalidade, sociabilidade e racionalidade materializam, com efeito, algo de comum a todo e qualquer membro da espécie humana.

Ao longo da história, é importante notar, várias concepções antropológicas sobre a natureza humana foram delineadas. Esforçando-se para entender a si próprio, o ser humano sempre procurou, ainda que o tenha feito de modo mais maduro e profundo com o despertar da filosofia, dar uma resposta de sentido sobre o que ele mesmo é. Muitas vezes, entretanto, a discussão sobre a sua própria consistência ontológica se revelou reducionista. Platão e Nietzsche, por exemplo, dois dos mais influentes autores da cultura ocidental, clássica e contemporânea, respectivamente, radicalizam - cada qual ao seu modo - um dos aspectos constitutivos do ser humano à revelia do outro. 
Para o dualismo antropológico de Platão (2011, 66b-67b), descrito sobretudo no Fédon, a alma é a verdadeira essência humana, querendo libertar-se do cárcere do corpo para, separada, existir em si e por si, num âmbito puramente racional e dissociado das paixões e desejos que animalizam e escravizam o indivíduo. Por sua vez, Nietzsche (2002, p. 47) concebe o homem como um ente dotado de um único princípio vital: "tudo é corpo e nada mais", posição que influencia estudiosos importantes como Sartre e Marcuse, os quais tomam a matéria como a totalidade do homem (SGRECCIA, 2002, p. 121).

0 erro destes autores, ao que se indica - sejam aqueles que exaltam um dualismo maldizente do corpo, sejam os apegados a uma condição exclusiva do homem -, é ignorar a complementaridade das causas primeiras; equívoco do qual o mais renomado filósofo a se afastar foi, certamente, Tomás de Aquino.

Aquino, inspirado pela fé cristã e acolhendo o pensamento aristotélico, entende que a união entre o físico e o anímico encontra semelhança com a assentada entre a matéria e a forma: inobstante ao fato de serem ontologicamente distintos, tanto o corpo quanto a alma não gozam de nenhuma autonomia antes da união, e sim a partir dela, momento em que a alma, na qualidade de princípio formal, comunica ao corpo as determinações de ordem animal, social e racional que nela mesma estão infundidas. Como resultado, concretiza-se a unidade anímico-corpórea, uma unidade não casual e fortuita, mas substancial. Daí afirmar o Aquinate que, "sendo a alma uma parte da natureza humana, só possui sua perfeição natural em sua união com o corpo, por isso não seria conveniente que fosse criada sem ele" (2003b, ST, I, q. 90, a.4).

Em outras palavras, para Aquino, o homem não é puro espírito nem uma mera matéria; tem o corpo e a alma como elementos totalizantes da sua natureza racional. 0 primeiro é realidade determinada por uma forma, isto é, é matéria informada; a segunda, é aquilo que determina e concretiza a matéria ao compartilhar o seu ser, ou seja, é a forma propriamente dita.

A alma, portanto, confere à corporeidade determinações concretas, a capacita integralmente; contudo, isto não significa que ela mesma se ache em independência plena em relação ao corpo, como algo totalmente alheio a ele. 0 corpo somente encontra plenitude quando informado pela 
alma e esta também só atinge a sua perfeição quando informa o corpo. Trata-se de uma relação polarizante e implicativa, em que duas realidades substancialmente diferentes se exigem reciprocamente para atingir a excelência natural; excelência pela qual a matéria inanimada torna-se matéria viva a partir da vivificação anímica.

Assim, desdobra-se que "todo elemento do corpo humano é humano, e existe como tal em virtude da existência imaterial da alma humana" (MARITAIN, 1952, p. 57, tradução nossa). As células, os tecidos, os órgãos e os sistemas são o que são por conta do compartilhamento do ser da alma, o que por si só é suficiente para anunciar as qualidades concretas inerentes ao homem como anímicas por origem e corpóreas por necessidade - afinal, é por intermédio do corpo que o invisível se torna visível, realidade encarnada no espaço e no tempo. Essa complementaridade, parece, rompe definitivamente com a representação do corpo como tumba do substrato anímico e fonte punitiva do homem. Rompe, igualmente, com os que reduzem todos os fenômenos vitais à matéria ou a um suporte espiritual. Pela intimidade profunda entre corpo e alma, o homem se configura concretamente, se exprime, estabelece vínculos, assume compromissos, erra e acerta, sofre e sorri.

Nesse sentido, não obstante a diversidade filosófica de concepções antropológicas sobre a natureza humana, pode-se afirmar que o ser humano goza de duas dimensões, uma física e outra anímica. Onde quer que se encontre está aquilo que lhe é intrínseco e imutável, absoluto e acabado: a natureza humana, expressão da correlação unitária e dinâmica entre um corpo não adstrito unicamente aos impulsos animais - mas constituído pela sociabilidade e racionalidade - e uma alma que a ele comunica essas operações vitais. Dito em outro tom, o homem existe como síntese integrante de determinações ordenadas segundo um espírito racional, como um ser preenchido por um fundamento de arranjo material e imaterial marcado pela complementaridade, e não pela casualidade.

Pouco valem as considerações filosóficas acima quando não se leva em conta a ocasião biológica da origem da matéria e forma humanas. Não teria sentido algum falar do que vem a ser a natureza humana se não se apreciasse, em conjunto, o seu princípio. 
Como visto na seção anterior, os dados da Biologia contemporânea apontam claramente para o genoma como elemento corpóreo que possibilita o desenvolvimento ininterrupto e gradual do nascituro. Assim, da exigência de uma densa compenetração entre o biológico e o filosófico, não resta outra conclusão senão a de que o ato existencial do corpo e da alma e, consequentemente, do homem, está adstrito aos dois processos biológicos marcados pela possibilidade de consubstanciarem um novo genoma: a concepção e a cisão gemelar. Ou seja, no exato momento da fecundação ou da referida cisão, surgem, concomitantemente, a matéria animada e a forma animante, e é em virtude de tal concomitância que a matéria emerge imediata e plenamente informada.

Por aí se reitera que a trama da vida humana inicia com o primeiro estágio de desenvolvimento do embrião, o zigoto, que desponta, desde logo, como genuíno substrato material da forma, um substrato preparado, em sua totalidade, para amadurecer e perpassar por todas as fases do existir humano, desde o período embrionário até a velhice. Durante a gestação inexiste uma passagem de não ser humano para ser humano, uma espécie de salto qualitativo. Quem se modifica é o embrião (biologicamente), não a natureza, que permanece constituída pela mesma matéria e forma.

É certo, então, que: ou um jovem, adulto ou idoso é ser humano e o embrião também é ser humano, ou o embrião não é ser humano e, consequentemente, ninguém o é. 0 homem não é quem foi em seu primeiro ou último suspiro; ele é quem foi durante todo o seu existir. Com a fertilização, a animalidade desponta imediatamente como impulso para garantir a sobrevivência, momento em que toda a coordenação empreendida pelo zigoto para garantir a continuidade e gradualidade do seu desenvolvimento já é produto da animação provocada pela alma. 0 mesmo pode-se dizer da sociabilidade, na medida em que o neoconcebido logo inaugura intensa interação com a mãe, que automaticamente permite a movimentação do seu filho por meio do epitélio ciliado e do peristaltismo existente em sua tuba uterina.

É justo questionar, todavia, como pode o embrião unicelular gozar de natureza humana se não manifesta nenhuma faculdade mental, estando, em tese, alheio à racionalidade. Ora, no horizonte existencial do homem 
nem tudo lhe é essencial, estando a ele ligado, nas ditas fases do seu desenvolver, o que não é gênero ou definição - os chamados acidentes: determinações ou qualidades que, apesar de não pertencerem à natureza, acompanham-na num laço de eventualidade ou de derivação pelo que ela mesma é; laço esse que em nada altera o estatuto ontológico em si, que permanece absoluto e imutável (AQUINO, 2003b, ST, I, q. 77, a.1).

Se é bem verdade que o homem não é só carne e osso, um pedaço de matéria, e sim uma alma num corpo capaz de se exprimir no mundo e em relação ao mundo, é verdade também que seu corpo é dimensão constitutiva da sua natureza, marcando toda a sua existência. Idade, inteligência, saúde, renda, cor, classe social, gênero sexual, talento ou religião, são verdadeiros acidentes conexos à união corpo-alma, propriedades que não existem por si sós, numa humanidade abstrata, mas particularizadas em pessoas humanas de corpo e alma.

O neoconcebido, nesse sentido, já é inteiramente racional, apenas não manifesta sensivelmente tal determinação por uma questão acidental, a idade ou o breve tempo existencial que se liga à sua natureza. Dizer isso é importante porque, na espécie humana, indivíduo algum ignora o envelhecer ou existe sem cor. Alguns, é verdade, nem chegam a adoecer; no entanto, todos são intelectualmente limitados. Há indivíduos que almejam a perfeição; outros, não raro, a ignoram.

Os acidentes, com efeito, têm uma infinidade de combinações e, conquanto não componham a natureza em si, carregam um valor fundamental: são contingências que demonstram a impossibilidade lógica de se compreender um ser humano perfeito, e, por conseguinte, a incoerência de qualquer ideologia de base eugênica. Nenhuma natureza ou essência é concebível sem um acidente e nenhum acidente é pensável sem natureza ou essência.

Quer-se dizer, pois, que a simbiose corpórea e espiritual inerente ao homem - a natureza humana - se consolida sempre em termos acidentais. Por isso, pouco importa, do ponto de vista ontológico, a pigmentação da pele, o credo religioso ou o efetivo exercício das faculdades mentais (como no caso do nascituro). 0 ser humano, em verdade, jamais pode ser assimilado em abstrato, ao contrário, somente se faz reconhecível no efetivar-se do substrato anímico-corpóreo segundo acidentes. 


\section{A PERSONALIDADE HUMANA E A DIGNIDADE DO NASCITURO}

A seção anterior assentou que alma e corpo existem numa relação recíproca de mútua implicação, e que juntos são uma só entidade. 0 objetivo da seção atual é abordar outros dois tópicos imprescindíveis no estudo do ser humano em geral e do nascituro em particular: a personalidade e a dignidade.

Não se sabe ao certo a origem etimológica da palavra latina persona. Muito, de fato, se discutiu sobre o assunto, porém jamais se chegou a um consenso a seu respeito. Em todo caso, independentemente das controvérsias existentes, é certo que o termo pessoa se desvelou por quase toda a Idade Antiga mediante distintas e claras acepções: denotou personagens, posição social, aparência, pessoas gramaticais, sujeito de direitos, bem como veio a ser sinônimo de ser humano, sentido do qual emana o seu emprego usual no tempo hodierno. Nenhum desses significados, no entanto, plasmou a personalidade como algo intimamente conexo à natureza ou essência de uma entidade; longe disso, o trato pessoal era cambiante e não remetia a qualidades determinantes (SPAEMANN, 2012b).

Ao que tudo indica, foi o teólogo Tertuliano, em sua obra Adversus Praxean, datada dos anos 213-217, o primeiro autor a utilizar o termo de modo estranho às linhagens semânticas até então vigorantes. Se, antes, pessoa remontava aos aspectos externos do ser humano, ou mesmo ao homem enquanto tal, a partir do teólogo latino passou a designar - em um novo sentido não excludente - o ser que existe em si porque conhece e se relaciona (RATZINGER, 2011). Tertuliano tinha em mente as figuras divinas típicas da tradição cristã, o Pai, o Filho e o Espírito Santo, e da sua teologia resultou a pessoa como um tipo de ser, um ser fundamentalmente autônomo, autoconsciente e em diálogo com os seus pares. Dessa perspectiva a filosofia posterior se valeu para aplicar analogicamente ao homem, cuja natureza racional foi sempre um diferencial. Boécio, por exemplo, aduz que "pessoa é uma substância individual de natureza racional" (apud AQUINO, 2005a, ST, I, q. 29, a.1); definição que se tornou célebre e paradigmática, reconhecendo todo ser humano como entidade pessoal. Daí não haver qualquer imprecisão ao se falar em pessoa humana, 
porquanto o adjetivo empregado impõe o devido contraste ante a pessoa divina, cerne da apreensão ontológica da personalidade.

Há quem entenda, contudo, que a personalidade não se estende a todos os seres humanos. Afirmam tais autores, a exemplo de Peter Singer (2002) e Michael Tooley (1972), que nem todo indivíduo humano é consciente de si, a ponto de alcançar as suas próprias qualidades e pulsões. Seria o caso dos nascituros, dos neonatos, dos portadores de doenças ou condições que afetam a atividade cognitiva, daqueles que se encontram em um estado de consciência do qual não podem ser despertados, etc.

Ora, já foi aludido que a natureza do homem se consubstancia sempre em termos acidentais. Pautada, pois, pelas propriedades do gênero humano, a pessoa humana somente pode ser concebida a partir da efetivação da sua natureza segundo acidentes, os quais - como dito há pouco -, ainda que mitigantes ou anulantes da expressão sensível de qualquer determinação concreta, em nada mudam a natureza em si, fonte da personalidade, que permanece união substancial entre corpo e alma. Em verdade, uma vez pertencente ao gênero humano, já se é integralmente animal, social e racional, assim como necessariamente já se é pessoa.

Isso significa que o ser humano traz algo de especial. Constituído por um estatuto ontológico substantivo da individualidade e da racionalidade que caracterizam a condição pessoal, ele participa de grau elevado na ordem dos seres; está embrenhado de dignidade. O ser humano tem um valor próprio, uma excelência máxima. De fato, gozando da correlação unitária entre corpo e alma racional, ele se expressa como ente capaz de conhecer a si mesmo mediante uma interpretação íntima, e isso o faz realidade habilitada para substanciar distintos preceitos axiológicos; preceitos aptos a promover o aprimoramento de todo e qualquer indivíduo humano. Em palavras mais simples, na humanidade há uma eminência que se vincula a um estatuto ontológico que é princípio da personalidade e da vida ética.

Por aí se vê que o ser humano é digno sem nenhum relativismo, "pois a dignidade é um absoluto e pertence à essência” (AQUINO, 2003a, ST, I, q. 42, a.4), fazendo-se imprescindível declará-la no indivíduo concreto e uno, a pessoa, como faz Tomás de Aquino, (2003a, ST, I, q. 29, a.3), ao afirmar ser "muito digno subsistir em natureza racional". 
Sendo, então, absolutamente valioso, ao homem se associam de maneira profunda distintos valores ou bens que dão forma e substância a diversos direitos e deveres fundamentais: vida, liberdade, igualdade, educação, trabalho, meio ambiente, entre outros, são paradigmas axiológicos que, pela sua fundamentalidade para a conservação humana, ultrapassam o tempo histórico como constantes perenemente exigíveis no universo jurídico.

Nesse sentido, provado biologicamente quando e como surge um todo individual humano, e demonstrado filosoficamente a natureza antropológica corpórea-anímica deste mesmo todo, pode-se afirmar, eticamente, que o aborto provocado é um exemplo de atentado contra a dignidade da pessoa humana: no exato momento da fecundação concretiza-se uma correlação profunda entre corpo e alma, e isto implica afirmar que ali, no útero materno, está plenamente individualizado um ser que é humano e, por isso, digno; uma pessoa que merece estima máxima, a começar pelo direito de não ser intencionalmente morta. Privar a continuidade vital de uma realidade humana digna como qualquer outra, seja qual for a razão, é uma experiência valorativa que não deve ser admitida em nenhuma comunidade. A vida faz parte do que há de mais profundo no homem; ela é expressão de um princípio anímico sem o qual sequer haveria uma natureza e uma dignidade correspondente. Dizer isso é imprescindível, porque, sendo a pessoa humana digna em razão do seu fundamento corpóreo-anímico, a vida - na qualidade de elemento constitutivo formal desse mesmo fundamento - participa de tamanha dignidade. Ela não é só responsável pela existência de um ser digno em si, é também princípio ativo da natureza que comporta tal grandeza, de maneira que violá-la intencionalmente, em qualquer circunstância, consiste numa afronta a um direito fundamental superior.

Nunca se tem demasiada vitalidade; é possível, contudo, que se tenha demasiada liberdade ou privacidade. Consequentemente, uma violação ao direito subjetivo de permanecer vivo somente é passível de justificação ética se for um efeito colateral de um ato que vise a garantir um bem de equivalência igual, ou seja, um ato que se atenha, igualmente, ao direito subjetivo de permanecer vivo. 


\section{A PROIBIÇÃO DO ABORTO VOLUNTÁRIO, O CÓDIGO PENAL BRASILEIRO E A AÇÃO DE DESCUMPRIMENTO DE PRECEI- TO FUNDAMENTAL no 54}

Ainda não se apresentou um conceito de aborto, embora já se o tenha mencionado ao longo deste artigo. Entretanto, uma vez entendido o estatuto do nascituro, isto é, a sua personalidade humana digna, pouco esforço é necessário para se verificar que a prática abortiva é sinônimo de morte. Aborto é, por definição, toda interrupção voluntária ou não da gravidez, que culmina no óbito do embrião ou do feto.

Nesta seção, primeiro demonstra-se a irracionalidade do abortamento voluntário e os equívocos dos artigos 124, 125 e 126 do Código Penal brasileiro; em seguida, explica-se no que consiste o princípio ético do duplo efeito e quais são os erros do artigo 128 da mesma lei; por fim, analisa-se a inconsistência argumentativa da Ação de Descumprimento de Preceito Fundamental n. 54, que tratou, em 2012, do aborto no caso dos fetos anencefálicos.

\section{A IRRACIONALIDADE DO ABORTO VOLUNTÁRIO, O PRINCÍPIO DO DUPLO EFEITO E O CÓDIGO PENAL BRASILEIRO}

O aborto voluntário, também chamado de aborto direto, é aquele no qual a interrupção da gravidez é praticada intencionalmente. Trata-se, pois, do aborto em que "a mulher ou outro agente deseja o fim da gestação e [em geral] o faz mediante procedimento cirúrgico ou indução química" (EBERL, 2006, p. 63). Por outras palavras, consiste na interrupção da gravidez com a consequente interrupção do processo vital já iniciado desde a concepção.

Em tais casos, diante do excursus biológico e filosófico realizado até aqui, não restam dúvidas de que a irracionalidade abortiva pode ser exposta logicamente obedecendo à seguinte cadeia de argumentos: 
a) Primeiro argumento: Todo nascituro da espécie Homo sapiens é pessoa humana digna da máxima estima, não podendo, por isso, ser privado do direito de continuar a existir. Cessar deliberadamente o seu desenvolvimento, levando-o à morte, consiste numa afronta ao seu direito à vida - o mais importante dos direitos - e, por conseguinte, à sua dignidade, consubstanciando um ato antiético e ilícito que não deve ser tolerado moralmente e permitido juridicamente.

b) Segundo argumento: 0 aborto voluntário, em qualquer fase de desenvolvimento do nascituro, visa deliberadamente a cessar o seu desenvolvimento, levando-o à morte.

c) Conclusão: Logo, o aborto voluntário, em qualquer fase de desenvolvimento do nascituro, consiste numa afronta ao seu direito à vida - o mais importante dos direitos - e, por conseguinte, à sua dignidade, consubstanciando um ato antiético e ilícito que não deve ser tolerado moralmente e permitido juridicamente.

Ora, se racionalmente se chega à conclusão de que o aborto voluntário não deve ser aceito porque viola, seja no plano moral, seja no plano jurídico, o direito à vida e, naturalmente, a dignidade do nascituro, contrario sensu, incentivar, promover ou realizar abortos não é senão irracional. Fazer, pois, do aborto voluntário um fim consiste em ato incompatível com a racionalidade humana.

É interessante notar que Tomás de Aquino trata explicitamente desse tipo aborto. Diz ele que "quem fere uma mulher grávida pratica ação ilícita. Portanto, se daí resultar a morte da mulher ou do feto já animado, não escapará ao crime de homicídio" (2005b, ST, II-II q. 64, a.6.ad 2). Aquino realiza, por assim dizer, o juízo que muitos penalistas hesitam fazer: o aborto direto não é senão um homicídio; assertiva que se afigura correta diante da personalidade humana do nascituro.

Tem razão, com efeito, a legislação penal brasileira quando enuncia, em seus artigos 124, 125 e 126, que o aborto volitivo é crime, ou seja, é conduta ilícita grave merecedora de pena devidamente prevista em lei: 
Art. 124 - Provocar aborto em si mesma ou consentir que outrem lho provoque:

Pena - detenção, de um a três anos. [...]

Art. 125- Provocar aborto, sem o consentimento da gestante:

Pena - reclusão, de três a dez anos. [...]

Art. 126 - Provocar aborto com o consentimento da gestante:

Pena - reclusão, de um a quatro anos. (BRASIL, 1940).

É falha a legislação, no entanto, quando diferencia os crimes de aborto do crime de homicídio enunciado no artigo 121 da codificação criminal, o que culmina em previsão de sanção punitiva significativamente mais branda para quem comete ou consente com a prática abortiva, como se nascituro não fosse pessoa humana ou não estivesse no mesmo nível de personalidade e dignidade das demais pessoas. Nesse sentido, a legislação penal assume uma visão típica de um personalismo funcionalista, definindo pessoa humana como "um ser humano mais alguma coisa, sendo esta coisa uma função específica ou uma função localizada numa variável lista de habilidades" (PAYNE, 2014, p. 70-71, tradução nossa).

Este equívoco, aliás, afasta o aborteiro das circunstâncias de homicídio qualificado expostas pelo $\S 2^{\circ}$ do referido artigo 121 , ignorando que o nascituro é incapaz de se defender dos recursos utilizados para a realização do aborto, hipótese do inciso IV do parágrafo mencionado, bem como pode vir a ser intencionalmente morto por meios obviamente cruéis, tais quais a aspiração ou a craniotomia, hipóteses que se adequariam ao inciso III do mesmo parágrafo.

É preciso notar, por óbvio, que nem todo aborto se dá de maneira voluntária. Há também abortos involuntários, os quais costumam ser caracterizados como aqueles em que a morte do embrião ou do feto é um efeito colateral de um ato, e, portanto, não está cingida por alguma intencionalidade. Todavia, nada impede do ponto de vista lógico, analisando-se tão-somente a expressão involuntário, que no rol de abortos dessa natureza se coloque o aborto espontâneo, afinal este último não envolve nenhuma volição. Os estudiosos do assunto, não obstante, pre- 
ferem diferenciar abortos involuntários de abortos que se expressam com espontaneidade, entendendo que no primeiro há um ato humano, comissivo ou omissivo, e no segundo uma ocorrência alheia a uma atitude do intelecto. Esta posição, em nome da clareza dos fatos, parece ser o melhor caminho.

No que concerne à realidade prática, abortos não volitivamente ordenados sucedem quando, para se salvar a vida da mãe, realiza-se um procedimento médico (cirúrgico ou não) e colateralmente o nascituro vem a falecer. Exemplos de tais procedimentos incluem a remoção do útero materno tomado por um tumor maligno, a realização de quimioterapia em uma mulher grávida, a retirada da trompa uterina afetada pelo embrião em caso de gravidez ectópica, entre outros casos. 0 questionamento natural, em tais situações, é se subsiste razoabilidade nestas condutas médicas, e tudo indica que sim.

Tomás de Aquino, ao tratar da legítima defesa, instituiu o princípio ético que hoje é comumente denominado princípio do duplo efeito. Segundo esta ordem principiológica, um ato não perde a sua legitimidade moral se dele advém, proporcionalmente, um efeito mau que não é intencional em si mesmo, muito menos é um meio para que se atinja um efeito bom (AQUINO, 2005b, ST, II-II, q. 64, a. 7). Dito de outro modo, um ato é eticamente justificável quando:

a) Visa um efeito bom em si mesmo.

b) Produz um efeito mau não intencional em si mesmo (efeito colateral).

c) Seu efeito mau não é meio para se obter o efeito bom.

d) Há uma razão proporcional entre os seus efeitos.

Este princípio, aplicado nos casos de risco de morte para a gestante, oferece um supedâneo ético para a prática do aborto não volitivo. Ou seja, se o aborto for o único meio para se salvar a vida da gestante, na certeza, ou nos precisos indícios científicos, de que o prosseguimento da gravidez culminará na sua morte, se faz racional praticá-lo, porém não como um direito subjetivo da mulher, e sim - a priori - como uma excludente de 
ilicitude, um estado de necessidade. Diz-se que a priori se trata de estado de necessidade porque o aborto não volitivo pode vir a ser realizado, por exemplo, por fato voluntariamente provocado pela gestante (imagine-se uma agressão a si mesma), o que esvazia a causa especial de exclusão de ilicitude referente ao agente que promoveu o fato, sendo legítimo o aferimento de responsabilidade.

Não é demais ressaltar que não cabe ao médico, ao fazer uso do princípio do duplo efeito, emitir um juízo de valor, reconhecendo que a vida da mãe tem primazia ante a vida do nascituro. Como já dito, todos os seres humanos são pessoas igualmente dignas, de modo a não existir entre os membros da espécie humana nenhuma hierarquia axiológica. Por isso está correto John Finnis (1993, p. 552, tradução nossa), em sua compreensão de que uma lei justa, consonante com uma ética médica coerente com a dignidade humana, deve ser assim expressa:

Se a vida da mãe ou da criança só pode ser salva por algum procedimento médico que afete negativamente o outro, é permitido realizar esse procedimento com a intenção de salvar a vida, desde que tal procedimento seja o mais efetivo disponível para aumentar a probabilidade geral de que um ou outro (ou ambos) sobreviverão, ou seja, aumentar a probabilidade média de sobrevivência.

Pouco esforço é necessário também para se compreender que o princípio do duplo efeito em nada se coaduna com o aborto resultante de gravidez por estupro, posição que alguns autores tentam sustentar realizando uma ginástica lógica que envolve a chamada pílula do dia seguinte (EBERL, 2006). Quando se permite esse tipo de aborto, chamado muitas vezes de aborto sentimental ou aborto humanitário, afronta-se diretamente o primado axiológico da pessoa humana, desprezando-se a unicidade e a inviolabilidade do concepto em nome da liberdade, da honra e da privacidade; valores que ensejam distintos direitos, mas são incapazes - sob qualquer ponderação objetiva ou razão proporcional - de sobreporem-se à vida, tributária de máxima tutela jurídica, conforme já visto.

É inegável que uma gravidez originária de estupro é um grande drama. Nenhuma pessoa merece sofrer, muito menos uma mulher ser violentada. Por isso, a experiência da sua dor não pode ser algo estranho a nenhum 
indivíduo, que, no seio da vida ética, deve apreender esse mal como se sua experiência fosse; deve considerar o sofrimento de uma mulher torturada por um criminoso. Entretanto, racionalmente, não há como se permitir o sacrifício de outro ser digno e inocente como forma de expurgação de angústias, tristezas, ou mesmo de futuros transtornos psicossomáticos. 0 nascituro é tão digno de proteção quanto a mulher violentada.

Vê-se, pois, pelas sucintas linhas delineadas no presente tópico que é totalmente descabido o atual artigo 128 do Código Penal Brasileiro, o qual trata das exceções de punibilidade para o aborto. Assim reza o dispositivo:

Art. 128 - Não se pune o aborto praticado por médico: [...]

I - se não há outro meio de salvar a vida da gestante; [...]

II - se a gravidez resulta de estupro e o aborto é precedido de consentimento da gestante ou, quando incapaz, de seu representante legal (BRASIL, 1940).

Ora, a locução "se não há outro meio de salvar a vida da gestante" materializada no inciso I de tal preceituação sugere, claramente, que matar o nascituro de forma volitiva é um recurso permissível para se atingir um fim, dando em sua estrutura terminológica uma prioridade para a vida materna. Isto é, o referido inciso denota que um efeito bom pode ser atingido pelo mais perverso dos efeitos maus, a retirada intencional da vida de um inocente. Além disso, o inciso II do artigo 128 permite que a vida, cerne sem o qual a corporeidade não se constitui, possa ser diretamente mitigada por razões de foro íntimo e a pretexto de uma suposta liberdade, como se o livre agir pudesse estar desprovido de um compromisso autêntico com a preservação da existência de um ser humano plenamente digno.

Especialmente em relação a este último inciso, muitas são as razões da sua inconstitucionalidade, porém adentrar na seara do direito constitucional fugiria, neste momento, ao propósito visado por este artigo. Por ora, basta ter em mente que a legislação penal brasileira, ramo do Direito destinado a tratar das infrações que se revestem de maior gravidade para a ordem social, não tutela plenamente o direito à vida do nascituro, verdadeira pessoa humana, nos moldes demandados pelo seu estatuto 
ontológico, ferindo, assim, um dos principais fundamentos da República: a dignidade da pessoa humana (BRASIL, 1988, art. 1ํ, III).

\section{A INCONSISTÊNCIA DA ARGUIÇÃO DE DESCUMPRIMENTO DE PRECEITO FUNDAMENTAL №. 54}

A Arguição de Descumprimento de Preceito Fundamental no. 54, de relatoria do Min. Marco Aurélio, demonstra fragilidade na sua fundamentação biológica e filosófica. Ajuizada, em 2004, pela Confederação Nacional dos Trabalhadores na Saúde (CNTS), tratou da inconstitucionalidade da exegese que reconhecia como crime contra a vida o aborto de nascituro anencéfalo, com base nos dispositivos 124, 126 e 128, I e II, do Código Penal, tratados anteriormente.

Entendia a entidade postulante que a criminalização da interrupção voluntária da gravidez, nos casos de anencefalia, violava os arts. 1ํㅡ, III (dignidade da pessoa humana); 5o, II, (princípio da liberdade e legalidade); 6º caput, e 196 (direito à saúde) da Constituição Cidadã de 1988. E assim também veio a entender, em abril de 2012, o Supremo Tribunal, ao julgar procedente a arguição (BRASIL, 2012).

Entre as muitas teses que envolvem o julgado, e levaram oito de dez Ministros da Suprema Corte do Brasil (o Min. Dias Toffoli julgou-se impedido) a permitirem o aborto de anencéfalos, cinco merecem atenção especial, estando diretamente relacionadas a tudo o que foi dito até aqui.

A primeira tese fundante da Ação de Descumprimento de Preceito Fundamental no 54 consiste no reconhecimento de que, sem a plenitude das estruturas cerebrais, inexiste vida (BRASIL, 2012). Sendo o anencefálico, por definição, um ser caracterizado pela ausência parcial do encéfalo e do crânio, e, consequentemente, pela ausência de importantes partes do cérebro, haveria, segundo o Supremo Tribunal Federal (STF), uma incompatibilidade entre anencefalia e vida. 0 simples fato de se invocar o direito à vida para um ser assim constituído seria, em si, um absurdo, devendo antes se aceitar que, havendo defeito no fechamento do tubo neural, o que está em jogo é a morte, e não o viver. 
Tal posição é um desacerto. Como já visto, a vida inicia antes da formação do sistema nervoso central, que, embora seja fundamental para que se continue a existir, não é a causa da vitalidade. Em verdade, a existência individualizada, isto é, como um todo vivo e não como parte de um todo vivo, tem começo com a fertilização, estando o nascituro dotado de tudo o que precisa para orientar o corpo materno desde quando unicelular: coordenação, excitabilidade e caracteres humanos. Isso significa que já é o concebido composto pelo substrato anímico que faz da corporeidade aquilo que ela é, numa relação implicativa e polarizante que anuncia a vida. A morte, com efeito, exige a cessação da unidade existente, e não é a funcionalidade limitada do cérebro que irá rompê-la; isto é, a morte pressupõe a desorganização dos elementos que compõem a unidade orgânica e garantem a manifestação das suas propriedades vitais. Uma pessoa com morte cerebral, portanto, não está morta, mas morrendo. Sua unidade pouco a pouco se corrompe, e a vida deixa de ser.

De tal sorte, o anencéfalo é ente ontologicamente uno, um ser vivo pleno para quem a vida será curta, porém digna de respeito absoluto. Não há, pois, de se falar em viabilidade vital. Vida é vida, com ou sem anencefalia; é ato irredutível à mera potencialidade. Já se trata de uma pessoa em ato, independente do grau de atualização de suas potências, que é sempre acidental.

A segunda tese vitoriosa na Ação de Descumprimento de Preceito Fundamental no 54 reside na suposta humanidade não pessoal do anencéfalo (BRASIL, 2012). Do ponto de vista filosófico (antropológico e ético), essa é talvez a mais frágil e insustentável das posições já levantadas pelo Supremo Tribunal Federal. Todo ser humano é pessoa, não havendo possibilidade conceitual de restringir esse atributo peculiar a apenas alguns privilegiados, visto que a dignidade deriva da natureza humana, e não de uma concessão social. Como tribunal superior do País, o Supremo não tem o poder de conferir personalidade humana aos indivíduos, tampouco pode considerá-los seres humanos não pessoais.

Como visto acima, a pessoa humana jamais pode ser assimilada em abstrato, apenas em conformidade com os acidentes que se vinculam à natureza que a substancia. $\mathrm{O}$ anencefálico, tal como qualquer nascituro, 
já é inteiramente um ser pessoal, se ligando à sua natureza não só o acidente da idade, como também o acidente da má-formação congênita.

A terceira tese prevalente na Ação de Descumprimento de Preceito Fundamental no 54 é a ausência de conflitos entre direitos fundamentais (BRASIL, 2012). Para o Pretório Excelso, como o anencéfalo não goza de vida potencial, haveria apenas um aparente confronto axiológico no interior da lide jurídica. Na realidade, só subsistiriam os direitos da mulher, isto é, a liberdade, a autonomia, a privacidade, a integridade físico-moral e a saúde, todos previstos pela Constituição Federal como bens jurídicos fundados na dignidade humana.

Adotar deste prisma é um erro. 0 anencéfalo: (a) goza de vida tanto quanto outro ser humano; (b) é ontologicamente uma realidade animal, social e racional, pois é membro da espécie humana; e (c) tem eminência máxima pelo simples fato de comportar uma unidade substancial entre corpo e alma. Caso não se concorde com isso, restarão dúvidas, e não aderir à ordem principiológica in dubio pro vita é incompatível com o princípio da dignidade humana, insculpido na Constituição da República, da qual o Supremo Tribunal Federal é o guardião máximo. Privado de solidez na argumentação técnica e ética, o resultado jurídico é uma infundada decisão de conveniência.

A quarta tese triunfante na Ação de Descumprimento de Preceito Fundamental no 54 fundamenta-se na hipotética inexistência de primazia do direito à vida perante os demais direitos; fato esse, segundo o Supremo, inquestionável (BRASIL, 2012). Ora, a mortificação equivale à destruição de uma realidade completa em si, um indivíduo, e é essa a maior privação a ser suportada por alguém. Tirar uma vida somente tem sentido como um efeito mau não intencional em si, voltado para se preservar outra vida, e mesmo nesse contexto, há sempre uma responsabilidade a ser aferida. Direitos fundamentais como o livre agir, a igualdade, o conhecimento, entre outros tão importantes, deve se subordinar ao direito elementar de viver, base do gozo de todos os outros direitos. Sem a vida, o homem não permanece, de maneira que destruí-la jamais constitui algo louvável em si.

A defesa dos direitos e garantias fundamentais da Constituição Federal baseia-se na lógica dos direitos humanos, que é a proteção máxima de todos os direitos compatíveis a todas as pessoas humanas, igualmente 
dignas, e que não podem ser discriminadas. Assim, a proteção da vida de todos, incluindo-se o nascituro, é dever do Estado e da sociedade, não podendo ser relativizada por argumentos infundados na ética da dignidade da pessoa humana.

Por fim, a quinta e última tese que merece atenção e gozou de prestígio na Ação de Descumprimento de Preceito Fundamental no 54 diz respeito à impossibilidade de se conceber o aborto de anencefálicos como um aborto eugênico (BRASIL, 2012). Segundo o Supremo Tribunal Federal, o anencéfalo e a vida são antíteses, não sendo possível, consequentemente, falar-se em eugenia. Repete-se aqui que o nascituro anencéfalo vive, e que inexiste o que se chama de potencialidade vital do neoconcebido. 0 aborto de um feto com deficiência no tubo neural é, de tal sorte, homicídio, e propaga, indubitavelmente, a cultura eugênica do mais saudável, perfeito, puro, forte, capacitado, belo, e assim por diante.

Resta claro, pois, que a Ação de Descumprimento de Preceito Fundamental no 54 não realiza a devida transposição das lições de arranjo biológico e filosófico, referentes ao estatuto ontológico do nascituro, para o plano jurídico nacional. A decisão do Supremo Tribunal Federal não retrata a exigência que acompanha qualquer trabalho conexo à Ciência do Direito, cuja antiga acepção dada pelos jurisconsultos romanos, Jurisprudentia, remonta a uma das virtudes primeiras do ser humano: um atento senso de mensuração entre os excessos. De fato, a Ação de Descumprimento de Preceito Fundamental no 54 consubstancia uma complementaridade epistemológica precária e, naturalmente, afasta o ordenamento jurídico brasileiro de um exame mais lógico e coerente da realidade biológica e filosófica (antropológica e ética) do ser humano.

\section{CONCLUSÃO}

Somente mediante um estudo interdisciplinar, especialmente um estudo que promova o encontro entre Biologia, Filosofia e Direito, se faz possível chegar a uma compreensão mais profunda sobre a existência ou não de um fundamento racional para a prática do aborto volitivo, bem como uma reflexão rigorosa quanto à extensão do direito à vida relati- 
vamente ao nascituro. Uma pesquisa bioética e biojurídica conjugada é imprescindível para que cientistas, filósofos e juristas adquiram um entendimento sólido sobre o embrião e o feto, de tal sorte que a dignidade da pessoa humana seja honrada e os seus direitos fundamentais sejam respeitados desde o primeiro ato existencial, consoante a lógica da afirmação histórica dos direitos humanos.

Do ponto de vista biológico, há razões suficientes para se reconhecer a individualidade humana do nascituro logo após o processo de concepção. 0 embrião unicelular, o zigoto, já possui uma carga genética própria, sendo coordenado de imediato pelo seu genoma para desenvolver-se de maneira contínua e gradual até a maturidade do gênero humano. Excepcionalmente, no entanto, um todo vivo e humano pode surgir a partir da cisão gemelar inerente aos chamados gêmeos monozigóticos. Neste caso, desdobra-se uma divisão que permite a continuidade do amadurecimento gradativo do embrião oriundo da concepção e o início de um novo ciclo vital por parte de um segundo embrião. Ou seja, manifesta-se um fenômeno biológico que, a um só tempo, não rompe com a unidade orgânica já existente e estrutura a existência de outra unidade. A unidade orgânica é, aliás, a causa da vitalidade de todo e qualquer ser humano, razão pela qual a alegação de que a vida tem início apenas com a concretização do sistema nervoso central está equivocada, segundo a ciência biológico-genética atual. Vive aquele que dispõe da organização integrada dos elementos que o compõem; organização essa que tem início com o término do processo de concepção. Portanto, à luz da biologia, o nascituro é uma realidade viva e completa em si; um ser que não mais passará por nenhuma novidade ontológica, já se desenvolvendo na plenitude da condição humana, a qual é marcada por incontáveis acidentes, mudanças que não alteram a sua forma humana personalizada, até a sua consumação com a morte.

Seria um desacerto, contudo, imaginar que o concepto se reduz a aspectos estritamente corpóreos. Como ser humano, ele goza da união substancial entre corpo e alma; é ente constituído por uma matéria animicamente ordenada segundo determinações de ordem animal, social e racional. Isso implica dizer que o embrião e o feto - conquanto não tenham a aparência típica de ser humano - não são meras potências humanas, 
e sim seres humanos em ato. Assim, preenchido pelas propriedades do gênero humano, o nascituro manifesta sem demora a sua animalidade e sociabilidade, movimentando-se pelas tubas uterinas com o auxílio do corpo materno, num impulso de autopreservação e interação. Ademais, expressa ontologicamente sua racionalidade, embora não o faça sensivelmente, porque à sua natureza se ligam acidentes, a começar pela idade e nível de desenvolvimento mental.

Por essa razão, uma consideração eugênica é um despropósito e, eticamente, um contrassenso, no contexto da afirmação universal dos direitos humanos em geral e da Constituição Federal do Brasil em particular, que garante a todos o direito à vida, sem qualquer discriminação, consoante o princípio da dignidade da pessoa humana (BRASIL, 1988, arts. 1ํ, III, e 5ำ caput). Em verdade, o estatuto ontológico humano somente pode ser compreendido a partir da efetivação do cerne corpóreo-espiritual em termos acidentais. Não à toa um personalismo funcionalista é ilógico. A pessoa humana é aquela que tem natureza humana, e, como tal, em nada se afasta de acidentes dos mais variados tipos. Isto é, todo ser humano é pessoa e sempre o será pela totalidade do existir. 0 zigoto é pessoa, o feto é pessoa, o anencefálico é pessoa, o microcefálico é pessoa, o portador da Síndrome de Down é pessoa, o doente de Alzheimer é pessoa, e, com eles - tão marginalizados -, cada membro da espécie humana é completamente pessoa: uma realidade individualizada de natureza racional. Os direitos basilares, constitucionalmente positivados, servem exatamente à proteção desses seres humanos dignos, porém excluídos da sociedade, ameaçados no direito fundamental de poder continuar existindo apenas por apresentarem certos acidentes que, de maneira nenhuma, os subtraem da natureza humana. Ao contrário, repita-se que todo ser humano individuado é uma pessoa que se desenvolve conforme acidentes, e não apenas o zigoto, o feto, o anencefálico, o microcefálico, o portador da Síndrome de Down, o doente de Alzheimer, entre os demais excluídos por características tidas em menor apreço.

Todo membro da espécie humana está também dotado de dignidade, um valor absoluto assente na sua própria natureza. 0 ser humano vale por seu estatuto, e isso basta. Nisso, repousa a dignidade da pessoa humana em que se fundam os direitos fundamentais. Em cada pessoa há 
o que nenhum outro ente possui, há uma unidade íntima entre corpo e alma racional que o faz pessoa. Apreendem-se, por conseguinte, como exigência de máximo respeito, bens e direitos fundamentais destinados a condicionar a experiência estimativa da pessoa humana ao mais alto grau na ordem dos seres. Entre esses bens e direitos, destaca-se a vida, cujo exagero inexiste. Quer dizer: ter vida jamais é um descomedimento, não podendo o mesmo ser dito em relação à liberdade, igualdade, honra, entre outros. Tirá-la equivale a cessar a existência, e não há maior infortúnio a ser suportado por qualquer ser vivo, em especial um ser digno, tal como a pessoa humana. De fato, o ser humano recebe o viver sem participar de sua própria concepção e traz em si o direito à autopreservação não como algo conquistado, e sim como um direito que com ele se origina; uma prerrogativa anterior a qualquer manifestação volitiva.

Vê-se, por aí, que o mais importante dos direitos, o direito à vida, abrange toda pessoa humana, e que, portanto, o aborto voluntário, ato que deliberadamente cessa o desenvolvimento e culmina na morte do nascituro, pessoa humana digna como qualquer outro ser humano, carece de fundamentos racionais. Interromper propositalmente uma gravidez é uma ofensa grave, uma prática que instrumentaliza o embrião ou o feto, renegando a sua dignidade ontológica e ética.

Em qualquer ordenamento jurídico, anunciar o direito de permanecer existente responde a uma imposição prévia, que o inspira e justifica. Ou melhor: é o fundamento que dirige do fortuito para o primordial, do relativo para o absoluto. Por isso falha o ordenamento jurídico brasileiro quando reconhece menor importância à vida do nascituro em sua codificação penal, com os artigos 124, 125, 126 e 128, e no âmbito jurisdicional, com a Ação de Descumprimento de Preceito Fundamental no 54. Falha também em outras diretrizes legais, as quais, contudo, dizem respeito a outros temas de arranjo bioético, e não constituem o objetivo deste artigo. É certo, de todo modo, que o nascituro deve ser respeitado e prezado não como se fosse um meio, mas como fim em si mesmo. Ele goza de significado originário em razão da sua própria natureza, e, nesse sentido, é digno como todas as outras pessoas humanas. 


\section{REFERÊNCIAS}

ANDERSON, Ryan. Faithful Reason about Stem Cells. Disponível em: <https:// www.firstthings.com/web-exclusives/2007/06/faithful-reason-about-stemcel>. Acesso em: 10 set. 2017.

AQUINO, Tomás de. Suma Teológica. v. 1. 2ª ed. São Paulo: Loyola, 2003a.

. Suma teológica. 2 ed. São Paulo: Loyola, 2003b. v. 2.

Suma teológica. 2 ed. São Paulo: Loyola, 2005a. v. 4.

Suma teológica. 2 ed. São Paulo: Loyola, 2005b. v. 6.

BRASIL. Congresso Nacional. Proposta de Emenda à Constituição no 181 de 2015. Disponível em:< http://www.camara.gov.br/proposicoesWeb/fichadetr amitacao?idProposicao=2075449>. Acesso em: 09 nov. 2017.

Governo Federal. Código Penal Brasileiro (Decreto-Lei no 2.848, de 1940). Disponível em: <http://www.planalto.gov.br/ccivil_03/decreto-lei/ Del2848compilado.htm >. Acesso em: 10 set. 2017.

. Supremo Tribunal Federal. Arguição de Descumprimento de Preceito Fundamental no. 54 de 2012. Relator: Ministro Marco Aurélio. Disponível em <http://www.stf.jus.br/portal/peticaoInicial/verPeticaoInicial.asp?base=ADP F\&s1=54\&processo=54> Acesso em: 22 set. 2017.

DWORKIN, Ronald. Life's dominion: an argument about abortion, euthanasia, and individual freedom. New York: Knopf, 1993. p. 70. Tradução nossa

EBERL, Jason. Thomistic principles and bioethics. London; New York: Routledge, 2006.

FEINBERG, Joel (Ed.). The Problem of abortion. Belmont, California: Wadsworth, c1984.

FERRAZ JÚNIOR, Tércio Sampaio. A ciência do direito. 2. ed. São Paulo, Atlas, 2010. 
FINNIS, John. Abortion and Health Care Ethics II. In: GILLON, Raanan (ed.). Principles of Health Care Ethics. Chichester: Wiley, 1993.

GEORGE, Robert; TOLLEFSEN, Christopher. Embryo: a defense of human life. [S.l.]: Knopf Doubleday, 2008.

LARSEN, William J. Human Embryology, 3. ed. New York: Churchill Livingstone, 2001.

MARITAIN, Jacques. The range of reason. New York, Scribner, 1952.

NIETZSCHE, Friedrich Wilhelm. Assim falava Zaratustra: um livro para todos e para ninguém. São Paulo: Martin Claret, 2002.

PAYNE, Craig. Aquinas and Bioethics. Ottumwa: Vision Publishing, 2014.

PLATÃO. Fédon. 3. ed. Tradução: Carlos Alberto Nunes. Belém: EDUFPA, 2011.

RATZINGER, Joseph. Dogma and Preaching. Translated by Matthew J. O'Connell. São Francisco: Ignatius Press, 2011.

SERRA, Angelo; COLOMBO, Roberto. Identidade e estatuto do embrião humano: a contribuição da biologia. In: CORREA, Juan de Dios Vial; SGRECCIA, Elio (Org.). Identidade e estatuto do embrião humano: atas da Terceira Assembléia da Pontifícia Academia para a Vida. Ananindeua, PA; Bauru, SP: CCFC: EDUSC, 2007.

SERRA, Angelo. Dignidade do embrião humano. In: Léxicon: termos ambíguos e discutidos sobre família, vida e questões éticas (Pontifício Conselho para a Família). Tradução de Cláudia Scolari. São Paulo: Editora Salesiana, 2004.

SIEGLER, Mark; WIKLER, Daniel. Brain death and live birth. Journal of the American Medical Association, Chicago, v. 248, n. 9, p. 1101-1102, sep. 1982.

SINGER, Peter. Ética prática. São Paulo: Martins Fontes, 2002. (Biblioteca Universal).

SPAEMANN, Robert. Love and the dignity of human life: on nature and natural law. Grand Rapids: W. B. Eerdmans, 2012a. 
. Persons: the difference between someone and something. New York: Oxford University Press Inc., 2012b.

TOOLEY, Michael. Abortion and Infanticide. Philosophy \& Public Affairs, New Jersey, v. 2, n. 1, p. 25-39, Aut. 1972. Disponível em: <http://science.kennesaw. edu/ echen1/Bioethics /Readings/readings/Tooley--Abortion $\% 20$ and $\% 2$ 0Infanticide.pdf>. Acesso em: 22 out. 2017.

WORLD HEALTH ORGANIZATION. Mechanism of action, safety and efficacy of intrauterine devices. Geneva, 1987. Disponível em: <http://apps.who.int/ iris/bitstream/10 665/38182/1/WHO_TRS_753.pdf>. Acesso em: 20 set. 2017.

Recebido em: 10-12-2017

Aprovado em: 31-1-2018

\section{Mário da Silva Ribeiro}

Mestrando em Direito pelo Programa de Pós-Graduação (PPGD) da Universidade Federal do Pará (UFPA). Bacharel em Direito pela Universidade Federal do Pará (UFPA). Coordenador do Grupo de Pesquisa "Bioética e o Direito à Vida" vinculado ao Grupo de Pesquisa (CNPq) "Tradição da Lei Natural".

E-mail: msribeiro1410@gmail.com

Universidade Federal do Pará

Rua Augusto Corrêa, 1 - Guamá - Belém - PA.

\section{Victor Sales Pinheiro}

Professor Adjunto da Universidade Federal do Pará (UFPA). Doutor e Mestre em Filosofia. Graduado em Direito. Coordenador do Grupo de Pesquisa (CNPq) "Tradição da Lei Natural".

E-mail: vvspinheiro@yahoo.com.br

Universidade Federal do Pará

Rua Augusto Corrêa, 1 - Guamá - Belém - PA 